\title{
THE COLONISATION OF LUTZOMYIA YOUNGI AND THE PUTATIVE ROLE OF FREE-LIVING NEMATODES IN THE BIOLOGY OF PHLEBOTOMINE SANDFLY LARVAE
}

\author{
KILLICK-KENDRICK M.*, KILLICK-KENDRICK R.*, AÑEZ N.**, \\ NIEVES E.**, SCORZA J.V.*** \& TANG Y.*
}

\section{Summary :}

A closed colony of Lutzomyia youngi Murillo \& Zeledón from the Venezuelan Andes was successfully established in the laboratory with a larval food containing two free-living nematodes (Coenorhabditis sp. and Aphelenchoides bicaudatus). This raises the question of the relationships between sandfly larvae and associated terrestrial fauna.

KEY WORDS : Lutzomyia youngi, phlebotomine sandflies, colonisation, freeliving nematodes, Caenorhabditis sp., Aphelenchoides bicaudatus.

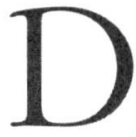
uring the past 20 years, improvements in methods of colonisation have led to the establishment of closed, productive sandfly colonies in laboratories in many parts of the world and more than two dozen species can now be bred in large numbers (Killick-Kendrick et al., 1991). There are, nevertheless, some species that appear impossible to adapt to laboratory conditions. One of these is Lutzomyia youngi Murillo \& Zeledón ${ }^{1}$, a highland fly of Venezuela and Costa Rica (Feliciangeli \& Murillo, 1987) and a probable vector of cutaneous leishmaniasis (Killick-Kendrick, 1990). Reports on rearing this fly in the laboratory were at first confusing because $L u$. youngi was not distinguished from $L u$. townsendi (Ortiz) until 1986. However, it is now known that Scorza et al. (1968) worked with Lu. townsendi (from Rancho Grande, Venezuela) whereas Castro \& Scorza (1977) and Añez \& Oviedo (1985) studied Lu. youngi

\footnotetext{
* Department of Biology, Imperial College at Silwood Park, Ascot, Berks SL5 7PY, UK.

** Departamento de Biologia, Facultad de Ciencas, Universidad de Los Andes, Mérida, Venezuela.

*** Departamento de Biologia, Facultad de Ciencas, Universidad de Los Andes, Trujillo, Venezuela.

Correspondence: M. Killick-Kendrick.
}

1. The authorities usually cited for this species are Feliciangeli \& Murillo, 1987. Their paper naming Lutzomyia youngi is, however, antedated by a publication by Murillo \& Zeledón (1986) with a description that appears to satisfy the International Code of Zoological Nomenclature (1985).
Résumé : ÉlEVAGE DE LUTZOMYIA YOUNGI ET RÔLE DES NÉMATODES LIBRES DANS LA BIOLOGIE DES LARVES DE PHLÉBOTOMES

Un élevage en continu de Lutzomyia youngi Murillo \& Zeledón originaire des Andes vénézuéliennes a pu être réalisé en laboratoire grâce à l'utilisation d'une nourriture larvaire contenant deux nématodes libres (Coenorhabditis sp. et Aphelenchoides bicaudatus). Ces résultats soulèvent l'intéressante question des relations entre les larves de phlébotomes et la faune terrestre associée.

MOTS CLÉS : Lutzomyia youngi, phlébotomes, élevage, nématodes libres, Caenorhabditis sp., Aphelenchoides bicaudatus.

(from the environs of Mérida, Venezuela). Neither species could be established as a permanent colony in the laboratory although, by feeding larvae of Lu. young $i$ on high protein diets (powdered prawns or Artemia salina), Añez \& Oviedo (1985) succeeded in rearing four consecutive generations (later extended to seven). This suggested that the larvae need a diet different from the ones currently used. There were, nevertheless, signs that the foods were not ideal in that the time of development was long, ecdysis from stage to stage was asynchronous, some pupae were deformed and late instar larvae were unusually active, escaping via the thread of the lid of the rearing pot as if searching for food. In the present note, we report the successful colonisation of Lu. youngi for 13 generations with a new larval food and in association with two free living nematodes.

Our colony originated from sandflies caught on a Shannon trap in a coffee plantation at Las Calderas, Trujillo (1,300 $\mathrm{m}$ a.s.l.), Venezuela, on three nights in the period September 3 to October 7, 1992. Full details of the methods used for the initiation of the colony are given by Killick-Kendrick \& Killick-Kendrick (1991). The flies were given blood meals on human volunteers and a total of 564 engorged females were later transferred to three $500 \mathrm{ml}$ plastic pots lined with plaster of Paris. On October 9-10, 1994, they were taken on in an insulated bag containing ice to Imperial College at Silwood Park, Ascot, UK. On arrival, 186 females in pot 1 were found to have laid 880 eggs and 214 females in pot 2 had laid 3,194 eggs. Of 
164 females in pot 3, 18 were alive. They were tubed individually and laid a total of 1,426 eggs.

The larvae were reared in $150 \mathrm{ml}$ pots made of polymethylpentene (Nalgene ${ }^{\mathrm{TM}}$ ). The base was cut off, the pot was placed on a piece of plate glass and then filled to about $1 \mathrm{~cm}$ with plaster of Paris. When the plaster was set, the sides of the pot were lined with more plaster and they were kept on damp sand in a snaptop plastic box. The eggs from pots 1 and 2 were distributed in 12 pots, each with 300 eggs and, after hatching, the larvae were fed on six different foods, namely: a) dried powdered Daphnia; b) an aerobically composted mixture $(1: 1 \mathrm{v} / \mathrm{v})$ of rabbit faeces and commercially available rabbit pellets (Lawyer et al., 1991) (= standard food); c) Daphnia + standard food $(1: 1 \mathrm{v} / \mathrm{v}) ;$ d $)$ Daphnia + standard food + dry, powdered coffee leaves (from Venezuela and Brazil) (2:2:1) ("Macbeth food "); e) " Macbeth food " + desiccated liver powder $(3: 1 \mathrm{v} / \mathrm{v})$; and $f)$ " Macbeth food " + dried yeast $(3: 1 \mathrm{v} / \mathrm{v})$. The productivity of the pots and the minimum times of development of the four larval stages were recorded. High yields, synchronous ecdysis of larval instars and short developmental times were taken as indications of good nutrition. Larvae were reared at different temperatures in the range $22-28^{\circ} \mathrm{C}$ and the mortality was recorded.

Adult flies were given a $50 \%(\mathrm{v} / \mathrm{v})$ sucrose solution on cotton wool, and females were fed on sedated hamsters. For the first few generations, engorged females were tubed individually for oviposition. As the colony increased in size, fed females were separated from males and unengorged females and held in a cage until defaecation before transferring them to pots for ovipostion. The larvae of $L u$. youngi are much smaller than those of other species we have reared and many died unless food was close to them as they emerged from the egg. As an innovation, the eggs were grouped together in the centre of the pot and surrounded with a ring of frass taken from a pot of the previous generation reared on Macbeth food. After hatching, all the larvae quickly moved into this frass and a fine dusting of food was added.

The shortest times of larval development and the maximum yields were obtained at $25^{\circ} \mathrm{C}$ with Macbeth food (two parts of composted rabbit faeces and rabbit chow, two parts Daphnia and one part powdered coffee leaves). With this food, 13 expanding generations of $L u$. young $i$ were reared. The addition of desiccated liver powder or yeast gave no advantage: both made the pots sticky and trapped larvae.

In the 6th generation, it was discovered that the colony had become contaminated with free-living nematodes. When checking the larval pots with a dissecting microscope, the nematodes were almost impossible to see because they quickly burrowed into the food in res- ponse to the light. However, when a sample of frass was examined in a Petri dish by transmitted light, hundreds of nematodes were immediately apparent. The nematodes were cultured in Petri dishes on half strength nutrient agar and two species, Aphelenchoides bicaudatus and Coenorbabditis sp., were found. These cosmopolitan nematodes were probably introduced with the dried coffee leaves in the Macbeth food. Unknowingly, the transfer of frass from pots of a previous generation when setting up the eggs carried the nematodes through each generation.

A. bicaudatus feeds on fungi (Hunt, 1993) and Coenorbabditis on bacteria. The frass in the pots remained like moist friable compost with no overgrowth of fungi, presumably because of the beneficial presence of the nematodes. The sandfly larvae grew uniformly with synchronous ecdysis, and no malformed pupae were seen. Not only did the nematodes appear to maintain the frass in good condition, but it is possible that they formed a useful source of protein in the food, particularly for the first instar larvae. Further work is necessary to find out the precise relationship between the nematodes and the sandfly larvae. Meanwhile, we routinely breed colonies of other species of sandflies with free-living nematodes in the larval pots, and we suggest that this method might be particularly helpful when colonising species such as Lutzomyia flaviscutellata (Mangabeira) which are difficult to rear because of contaminating fungi (Ward, 1977).

Sandfly larvae are terrestrial and, from the little that is known of the natural habitat, preferred places seem to be moist soil rich in organic matter. These are the precise requirements of the free living nematodes. Our observations raise the question of the interrelationships between the larvae of sandflies and the associated terrestrial fauna.

\section{ACKNOWLEDGEMENTS}

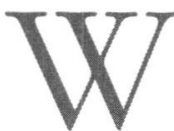

e thank Mr. Eric Brown for help in field collections, and Dr. D.J. Hunt for kindly identifying the nematodes and Dr. W.M.

Hominick for helpful advice. We acknowledge with thanks the financial support of the Leverhulme Trust (RK-K), the Medical Research Council, London (RK-K, MK-K), the British Council (RK-K) and the Oficina de Intercambio Cientifico ULA (NA).

\section{REFERENCES}

AÑez N. \& Oviedo M. Two new larval diets for rearing sandflies in the laboratory. Transactions of the Royal Society of Tropical Medicine and Hygiene, 1985, 79, 739-322. 
Castro T.A. \& Scorza J.V. Cultivo de Lutzomyia townsendi (Ortiz, 1959) (Diptera, Psychodidae) a partir de una populación alopátrica del estado Mérida, Venezuela. Boletin de la Dirección de Malariología y Saneamiento Ambiental, 1977, 17, 224-229.

Feliciangeli M.D. \& Murillo J. Lutzomyia youngi (Diptera: Psychodidae), a new phlebotomine sand fly previously misidentified as L. townsendi in endemic foci of cutaneous leishmaniasis in Venezuela and Costa Rica. Journal of Medical Entomology, 1987, 24, 141-146.

HunT D.J. Aphelenchida, Longidoridae and Trichodoridae: their systematics and bionomics, CAB International, Wallingford, 1993.

Killick-Kendrick M. \& Killick-Kendrick R. The initial establishment of sandfly colonies. Parassitologia, 1991, 33 , Suppl., 321-333.

KILLICK-KENDRICK R. Phlebotomine vectors of the leishmaniases: a review. Medical and Veterinary Entomology, 1990, 4, 1-24.

Killick-Kendrick R., Maroli M. \& Killick-Kendrick M. Bibliography on the colonization of phlebotomine sandflies. Parassitologia, 1991, 33, Suppl., 321-333.

Lawyer P.G., Rowton E., Perkins P., JOHnSON R.N. \& YOUnG D.G. Recent advances in laboratory mass rearing of phlebotomine sand flies. Parassitologia, 1991, 33, Suppl., 361364.

Murillo J. \& Zeledón R. Flebótomos de Costa Rica. Brenesia, 1985, No 23, Suppl., 5-137.

Scorza J.V., Gomez I. \& Ramirez M. Observaciones biológicas sobre algunos flebótomos de Rancho Grande (Venezuela). 3. Notas bionómicas sobre Phlebotomus townsendi Ortiz, 1959 y P. vexillarius Fairchild \& Hertig, 1952. Acta Biológica Venezuelica, 1968, 6, 28-40.

WARD R.D. The colonisation of Lutzomyia flaviscutellata (Diptera: Psychodidae), a vector of Leishmania mexicana amazonenesis in Brazil. Journal of Medical Entomology, 1977, 14, 469-476.

Reçu le 28 mars 1997

Accepté le 9 juin 1997 